\title{
Teaching Writing and Twenty First Century Skills Using Guided Autonomous Learning Designs
}

\author{
Abdul Ghofur ${ }^{1}$, Kisyani $^{2}$, Bambang Yulianto ${ }^{2}$ \\ ${ }^{1}$ Faculty of Language and Arts Universitas Negeri Medan, Medan, Indonesia \\ ${ }^{2}$ Faculty of Language and Arts Universitas Negeri Surabaya, Surabaya, Indonesia \\ ghofur@unimed.ac.id
}

\begin{abstract}
This article describe how to improve student's skills in writing French and eight types of the twenty first (21st) century skills Using Guided Autonomous Learning designs. This research is intended to produce and use Guided Autonomous Learning Designs by integrating eight types of 21 st century skills in teaching writing French. The designs developed consist of syllabus, learning model, textbook, learning media, and lesson plan. The research data is obtained from students, lecturers, experts, observers, and documents. Data sought are (1) process of developing Guided Autonomous Learning designs by integrating eight types of 21 st century skills and their quality based on their validity, practicality, and effectiveness. The data was collected using observation techniques, expert validation, interviews, documents analysis, tests, and questionnaires. The data was analyzed quantitatively and qualitatively using content analytic techniques, conversational analysis, narrative analysis, percentage techniques, average techniques, and correlation techniques. The finding show that Guided Autonomous Learning designs by integrating eight types of 21 st century skills are very effective to improve student's writing in French and eight types of $21 s t$ century skills. The average score of the quality (validity, practicality, and effectiveness) of Guided Autonomous Learning designs by integrating eight types of 21st century skills is 3.51. Therefore, this research needs to be developed and implemented in other subjects by integrating other types of 21 st century skills.
\end{abstract}

Keywords: learning designs; writing skills; $21^{\text {st }}$ century skills.

\section{Introduction}

The development of science and technology, especially in information and communication technology that is very fast in 21 st century era has a huge influence on the changes of the pattern of human life. The Changes are influenced by the demands of skills by $21^{\text {st }}$ century workforce. UNESCO has outlined $21^{\text {st }}$ century learning paradigm in the four visions of $21^{\text {st }}$ century education, they are: (1) learning to think, oriented to logical skills , (2) learning to do, oriented to problem solving skills, (3) learning to be, oriented to character building, and (4) learning to live together, oriented to be tolerant and work in team (Hidayat, 2013). According to Hanover Research (2011), there are 27 types of $21^{\text {st }}$ century skills that must be mastered by $21^{\text {st }}$ century students. Based on these concepts, $21^{\text {st }}$ century skills are really needed to be taught to students.

In connection with this phenomenon, the Government of Indonesia has issued Presidential Regulation, No 8 of 2012 concerning the Indonesian National Qualification Framework. In the Qualification Framework, bachelor graduates must master core subject in depth theoretically and practically and master several types of $21^{\text {st }}$ century skills. In this regard, the government developed guidelines for developing curriculum based on the Indonesian National Qualification Framework. In the guideline, it is stated that to compile studies and courses must refer to the Indonesian National Qualification Framework descriptors (Dikti, 2014). 
The strategy of curriculum development which is used by the Government of Indonesia has implication for the emergence of new courses to respond the descriptors of Indonesian National Qualification Framework thereby reducing the number of expertise course related to core subject, replaced by courses related to $21^{\text {st }}$ century skills. The impact of these strategies is the students quality declines on the expertise competency. This phenomenon was recognized by lecturers of French study program of Medan State University. According to the lecturers, there are differences in French language ability between the students who take the curriculum based on competency (previous curriculum) with the students who take the curriculum based on the Indonesian National Qualification Framework (curriculum that is being used). The students who take part in the curriculum based on competency have higher French language ability than the students who take the curriculum based on Indonesian National Qualification Framework when they are studying in the same semester.

Based on the preliminary study, French language skills of students in Medan State University, especially in writing are still low. On the other hand, $21^{\text {st }}$ century skills listed in the descriptor of Indonesian National Qualification Framework will be very difficult to be achieved because the number of courses related to $21^{\text {st }}$ century skills is insufficient. Therefore, an appropriate learning strategy is needed so that these two problems can be overcome. Strategy which is deemed appropriate to overcome these problems is by integrating of $21^{\text {st }}$ century skills in the learning designs, not by emerging courses related to 21 st century skills mentioned in the Indonesian National Qualification Framework descriptors. Therefore, using integrated curriculum approach is an effective strategy (Wang, 2014).

Given with many types of the $21^{\text {st }}$ century skills that must be mastered by students, it is impossible to integrate them in one course. In this regard, only eight types of skills were integrated in learning designs of writing French, they are: (1) cooperative and collaborative skills, (2) adaptability skills, (3) responsibility, (4) analytical data and information skills, (5) critical thinking and problem solving skills, (6) creativity, (7) communicating skills in oral and written, and (8) using information and communication technology skills. These eight skills are part of $21^{\text {st }}$ century skills that are listed in the Indonesian National Qualification Framework (Dikti, 2014).

In the digital era, learning of writing is not enough to be taught manually but must use information and communication technology as an instrument for storing data and publishing various information in order can be used by international community. Published papers must be accountable for its content correctness and its originality. This shows that between writing skills and the skills of using information and communication technology, as well as responsibility which are part of $21^{\text {st }}$ century skills are interrelated. Writing is also a process of critical and creative thinking because writing requires analysis of various choices of words and the process of developing new ideas. Therefore, the activity of writing is closely related to the activity of practicing several $21^{\text {st }}$ century skills.

In connection with the problems above, it is necessary to develop Guided Autonomous Learning designs by integrating eight types of the 21 st century skills. The designs developed must include planning aspect (learning outcomes), content (materials), learning process, and evaluation (Arifin, 2013). The planning aspect is represented by a syllabus and lesson plan. The content aspect is represented by the content of the textbook. Learning aspects can be represented by learning model and learning media. The evaluation aspect is represented by 
the instrument of test. All these aspects must integrated the eight types of the $21^{\text {st }}$ century skills and must be constructed in a single operation system.

Based on these descriptions, the objective of this research is to produce Guided Autonomous Learning designs by integrating eight types of 21 st century skills to improve student's skills in writing French and $21^{\text {st }}$ century skills for students.

\section{Review of Literature}

There were several researches that support the importance of the eight types of skills integrated in writing learning designs in this research. Strang (2015) stated that the implementation of collaborative learning model can improve exam results, reducing differences in views about gender, age, and ability. For this reason, students need to be trained in cooperative and collaborative skills in learning of writing. The implication of the implementation of cooperative and collaborative learning model can also affect the ability of students to adapt with variety situations and be responsible.

Bradshaw and Amanda Hazell (2017) said that teachers must be able to familiarize students with problem solving in learning because the activity is not rigid in nature and can train students to solve their problems. With problem solving, students will be encouraged to analyze data and information, critical thinking, and communicate through oral and written which is also part of $21^{\text {st }}$ century skills.

Petra (2016) said that the use of web-based learning supports students to become autonomous learners. This means that through web-based learning can train student skills using information and communication technology which can ultimately improve student learning outcomes. Beside, the student can publish their writing using information and communication technology.

Tong (2017) stated that to achieve $21^{\text {st }}$ century skills, it is necessary to change the mindset of lecturers and students from traditional learning model to innovative learning model. One of innovative learning is the use of information and communication technology in learning. The use of information and communication technology can increase student autonomous in learning because they can study anywhere without any assistance of lecturer.

Based on the preliminary study, a good strategy to improve competencies in core subject and to achieve the descriptors of Indonesian National Qualification Framework is not by emerging new courses related to $21^{\text {st }}$ century skills, but by integrating $21^{\text {st }}$ century skills in learning designs of every course. Thus, the number of course that support the core subject will be sufficient to equip students competency in the core subject. On the other hand, $21^{\text {st }}$ century skills can be trained to students maximally. All types of 21 st century skills can be integrated in each course based on the characteristics of the course. For this reason, it is necessary to use the concept of integrated learning. Integrated learning is learning that links a particular subject to another subject, carried out spontaneously or planned, both in one field of study and with a variety of student learning experiences (Trianto, 2015). The distinctive characteristics of integrated learning are authentic, meaningful, holistic, and active.

Given the magnitude of the demands of the life of $21^{\text {st }}$ century, students must be taught multi-literacy skills in order to be able to compete in the life in 21 st century era. Multiliteracy is a skill to understand ideas and informations by using of texts, symbols, and multimedia in various ways. Students must be able to understand and use various kind of texts, medias, and symbol systems to maximize their learning potential, follow technological 
changes, and actively participate in global communication (Abidin, 2015). This condition requires the important role of the teacher in the multi-literacy learning process. English and Marr (2015) mentioned that language teachers should not only be specialist in linguistics. Language teachers must be able to understand various other fields of science that use language as tool of communication. This is different from history teachers who only have to become historians, physics teachers must be physicked teachers, and so on.

\section{Research Method}

The object of this research is the development of Guided Autonomous Learning designs by integrating eight types of the $21^{\text {st }}$ century skills to improve French writing and $21^{\text {st }}$ century skills of students. Data collected were: (1) data on the process of developing Guided Autonomous Learning designs by integrating eight types of $21^{\text {st }}$ century skills and (2) the quality of Guided Autonomous Learning designs by integrating eight types of $21^{\text {st }}$ century skills in learning of writing French, in terms of validity, practicality, and it's effectiveness. This study used Fenrich's development theory (2005), consist five phase, namely (1) analysis, (2) planning, (3) design, (4) development, and (5) implementation.

Data of the process of developing the Guided Autonomous Learning designs was obtained through study the documents, interview, questionnaire, and observation. The data collected was analyzed using content analysis technique, conversational analysis technique, percentage formula, average formula, correlative technique, and narrative technique. Content analysis technique was used to analyze documents related to various knowledges in books, journals, and so on. Conversational technique was used to analyze data of interviews. The percentage formula was used to analyze the responses of lecturers and students to the questionnaire in the analysis phase and data of lecturer and student activities during the implementation. The average formula was used to analyze data of expert assessment, lecturers and students response in questionnaire after the implementation. The correlative technique was used to analyze the correlation students scores in pretest and posttest. The narrative technique was used to analyze data of process of developing the Guided Autonomous Learning designs in learning of writing French.

Data of the validity of the Guided Autonomous Learning designs were obtained through the assessment by three experts using assessment instruments of validity of the Guided Autonomous Learning designs. The data were analyzed using the average formula. The average score of each sub-aspect of the assessment given by validations was calculated and then the validity level was determined.

Data of the practicality of the Guided Autonomous Learning designs were obtained through: (1) experts assessment, (2) observations, (3) students assessment, and (4) lecturers assessment. The instruments used are: (1) practicality assessment sheet, (2) students and lecturer activity observation sheet, (3) lecturers response questionnaire, and (4) students response questionnaire. Data of experts assessment, lecturer assessment, and students assessment were analyzed using the average formula. The scores of each sub-aspects of assessments given by experts, students, and lecturers were calculated their average scores. Data of observation using instrument of student and lecturer activity observation sheet were analyzed using the percentage formula. Furthermore, these data was converted into average formula to obtain parallel scores with other assessments. Finally, they were calculated their 
average scores and concluded the practicality level of the Guided Autonomous Learning designs.

Data of the effectiveness of the Guided Autonomous Learning designs were obtained through: (1) correlation of the results of students pre-test and post-test using test instrument and (2) the students assessment toward the Guided Autonomous Learning designs using students questionnaire instrument. Data of students assessment recorded in questionnaire were analyzed using the average technique. The scores of each sub-aspect of the student assessment were calculated their average scores. The data of pre-test and post-test were analyzed using the SPSS program to get data normality score, paired sample statistical score, and paired sample correlation score. Furthermore, the results of the correlation score was converted into average formula in order to obtain parallel score with other assessments. Finally, they were calculated their average scores and concluded the effectiveness level of the Guided Autonomous Learning designs.

\section{Results and Discussion}

Based on the process of developing the Guided Autonomous Learning designs using Fenrich's development theory (2005), there were 5 learning designs developed, they are (1) syllabus of writing French level A-1 to B-2 , (2) Guided Autonomous Learning model, (3) a French textbook level A-1, (4) learning media (blog Mate-21), and (5) lesson plan for A-1 level. All designs developed, integrated eight types of $21^{\text {st }}$ century skills. The syllabus developed was the syllabus of writing French from A-1 to B-2 level because the French competency standard for bachelor is DELF level B-2. Guided Autonomous Learning model was developed because the syllabus developed requires a learning model that fits the characteristics of the syllabus. French writing textbook level A-1 was developed because the most important textbook needed by beginner students are a textbook level A-1. The design of the textbook level A-1 can be considered as representing the design of textbooks at the next level. Developed media Mate-21 was to help students to study autonomously and to train students in using information and communication technology. Finally, the lesson plan of writing French was developed only at DELF level A-1 because the design of the lesson plan can be considered as representing the design concept of the lesson plan of writing French that integrates $21^{\text {st }}$ century skills at the next level.

To develop the five learning designs, the syllabus must be developed first because the syllabus is main reference for developing other learning designs (learning model, textbook, learning media, and lesson plan). It means that the syntax of Guided Autonomous Learning model, textbook, learning media, and lesson plan by integrating eight types of $21^{\text {st }}$ century skills developed must be in accordance with the objectives and contents of the syllabus that integrates $21^{\text {st }}$ century skills. In this research, the development of the four learning designs must wait for the results of the development of the syllabus which has been declared valid by experts.

After the syllabus was declared valid by experts, Guided Autonomous Learning model was developed. The model must also be validated first by experts because the syntax of the learning model was used as a reference for constructing the textbook and learning media. After the Guided Autonomous Learning model was declared valid by experts, textbooks writing of French was developed, referred to the syntax of the Guided Autonomous Learning model, the objectives and learning material in the syllabus by integrating eight types of $21^{\text {st }}$ 
century skills. The French writing textbook must also be validated by experts because the format and content of textbooks were used as materials for developing the Guided Autonomous Learning Media. The lesson plan was developed after the learning media was declared valid by the experts. This development process has implications toward longer research time. But on the other hand, this process guarantees the quality of the guided autonomous learning designs developed. The five learning designs developed can have a unified objectives, contents, and constructions system.

Based on the results of experts' validation to the Guided Autonomous Learning designs by integrating $21^{\text {st }}$ century skills, the data of average validity value was 3.38 (in the valid category). Based on the data analysis on the practicality of the Guided Autonomous Learning designs obtained an average value of 3.65 (in the very practical category). As for the assessment of the effectiveness of the design of Guided Autonomous Learning design obtained average score of 3.51 (in the very effective category). Based on these three values, the average quality of the Guided Autonomous Learning designs was at 3.51 (in the very good category).

Based on the analysis of the process and results of the development of Guided Autonomous Learning designs, it found three research results, namely (1) the use of Guided Autonomous Learning design by integrating eight types of $21^{\text {st }}$ century skills is an effective strategy to improve learning outcomes in writing French and eight types of $21^{\text {st }}$ century skills for students, (2) external motivation has a very strong influence on the learning process and results, (3) the unity of the objectives, contents and constructions system of the Guided Autonomous Learning designs is very effective to improve the quality of learning processes and learning outcomes.

First, the integration of 21 st century skills in the designs of the Guided Autonomous Learning can represent the presence of new courses that are in accordance with the Indonesian National Qualification Framework descriptors associated with mastering $21^{\text {st }}$ century skills. Thus, the number expertise subject is not reduced, so it can guarantee the graduate competencies in the core subject. Furthermore, if the strategy is used in all subjects, students can be continuously trained all types of $21^{\text {st }}$ century skills. The implication of this strategy is the strengthening of student mastery $21^{\text {st }}$ century skills because they are taught continuously from the first semester to the final semester. This is certainly different if it is used a learning strategy that separates each skills. In the curriculum, the process of integrating a skill with other skills is known as the integrated curriculum.

In the curriculum there are three models of curriculum development approach, namely, (1) separated curriculum, (2) correlated curriculum, and (3) integrated curriculum (Arifin, 2013). In the separated curriculum, each skill is taught through certain subjects and taught separately (without any connection at all). This means that the more skills that are to be achieved will have implications for the more subjects that must be taught, while the maximum number of course in curriculum is limited. Therefore, if there is a reduction in the number (depth) of a course, it will have implications for the decline in the quality of student learning outcomes.

In the correlated curriculum, some skills can be taught simultaneously because these skills are interconnected. For example, in language learning, four language skills (reading, writing, listening, and speaking) can be taught simultaneously or taught based on language skills categories (productive skills or receptive skills) because in language activities are always related. Writing activities are always related to reading activities, while speaking 
activities are always related to listening activities. If learning of receptive skills is expanded into productive skills, all four language skills can be taught in one meeting (time).

On the integrated curriculum, some skills related to the core subject and other skills like soft skills can be taught simultaneously through developing activities that are in accordance with the types of skills that will be achieved. To master problem solving skills, it must not by emerging a specific course about problem solving, but it is enough to provide learning activities that train student about problem solving.

In this regard, to realize learning that integrates $21^{\text {st }}$ century skills, an integrated curriculum is needed both at the national level, institutional level, and courses level, and at the level of unit discussion. One of the implications of using an integrated curriculum is the use of integrated learning model and the use of web-based learning media. Through integrated learning, several skills can be taught in an integrated manner in learning a course. As for the use of web-based learning media, students can use information and communication technology as an instrument and source of autonomous learning.

Research related to them has been done by Staffan (2016) who stated that integrated learning can improve the learning process where knowledge and practice are integrated in the curriculum. Ranjan (2008) mentioned that the rapid development of Information Technology (IT) increasingly influenced the process of creating publications, disseminating educational materials and various other information. IT has facilitated connections across disciplinary, institutional, geographical, and cultural boundaries. IT-based computing and communication skills offer great hope to support continuous improvement in the academic world. Furthermore, Petra (2016) said that the use of web-based learning can encourage students to become autonomous learners.

If it refers to curriculum development procedures based on the Indonesian National Qualifications Framework, the curriculum developed in each study program in Indonesia is separated curriculum. This can be seen in the development of several courses to respond the learning outcomes related to $21^{\text {st }}$ century skills such as computer, leadership, etc. depending on the policies of each study program. This strategy will be very difficult to achieve graduated competency standards required by the Indonesian National Qualifications Framework, namely (1) able to master the core subject in depth both theoretically and practically and (2) master several types of $21^{\text {st }}$ century skills. The reason of the statement is the reduction of supporting course in core subject that will make a difficulty to achieve competency standards related to the core subject. On the other hand, the existence of supporting course of $21^{\text {st }}$ century skills at little number will make a difficulty to achieve competency standards related to $21^{\text {st }}$ century skills. In this regard, an integrated curriculum approach is used in developing the Guided Autonomous Learning designs. By using the integrated curriculum, 21st century skills are not taught through certain subjects but they are integrated in learning. Thus, the curriculum of the study program can be focused on mastering the core subject, while $21^{\text {st }}$ century skills is obtained through integrated learning activities related to $21^{\text {st }}$ century skills.

Second, external motivation has a very strong influence toward learning processes and outcomes. This topic is specifically discussed because there is motivational activities in the syntax of the Guided Autonomous Learning model developed. One of the research on motivation was carried out by Vishnu (2016) which stated that motivation significantly affected learning and memory of student. However, not many education experts have 
developed and discussed specific strategies for providing external motivation to increase student motivation and learning outcomes.

It must be realized that every student present in the class brings different experiences, knowledge, feelings, and thoughts. These differences can affect the high or low motivation of students. In this regard, the role of lecturer as external motivator is very important. Lecturer must be able to reduce the psychological burden of students and increase student motivation. For this reason, a strategy to provide external motivation is needed. In addition, the lecturer have to make sure that the motivation material is well prepared.

The lecturer must be realized that students activities in the classroom are driven by different needs. The difference in needs has implications toward differences students attitudes, motivations, and participation in the learning process. Learning objectives can be achieved more easily if the three differences can be harmonized by the lecturer. Therefore, the role of the lecturer in providing external motivation becomes very important. The ability of lecturers to motivate students to have high motivation to study autonomously is far more important than their ability to explain the material because the high desire of students for autonomous learning can greatly influence the learning outcomes. This statement is based on a comparison of the process and learning outcomes of students in classes that are less motivated and the process and work outcomes of sales executives who are highly motivated when carrying out their respective activities.

The development of learning designs that integrates 21 st century skills is one way to increase student motivation. The existence of cooperative learning, collaborative activities, inquiry, and problem solving in the syntax of Guided Autonomous Learning model by integrating eight types of 21 st century skills can help students to improve their learning outcomes. This is consistent with Strang's study (2015) which stated that collaborative learning models can help students to improve their exam results, reduce differences in views regarding gender, age, and ability. Laxman (2013) stated that inquiry learning can encourage students to discover new knowledge autonomously, improve problem solving skills, and can improve their higher thinking skills. Furthermore, Bradshaw (2017) stated that students must be accustomed to carry out problem solving activities in learning because the activity can train their critical thinking and problem solving skills.

The syntax of Guided Autonomous Learning design by integrating eight types of $21^{\text {st }}$ century skills consists of seven learning phases, they are: introduction, analysis of data and information, error analysis of sentence and problem solving, written communication online, self evaluation, learning evaluation, and closing. One important activity in the preliminary phase is the provision of external motivation by the lecturer. Delivering external motivation is carried out in an organized manner both the purpose, content, and delivery strategy. In the analysis of data and information phase, students seek knowledge cooperatively and collaboratively without any lecturer's assistance. Students discuss to find the data (knowledge) in each chapter of textbook. This phase is the training phase of cooperative and collaborative skills, responsible attitude, adaptability skills, and analytical information competency.

In the phase of error analysis of sentence and problem solving, students in groups discuss to find the errors in the sentences and revise it into the correct sentences. Sentences that are the object of discussion are sentences that are deliberately arranged incorrectly based on the subject matter in each chapter of the textbook. This phase is a phase of training in critical thinking and problem solving skills. In the phase of written communication online, 
students are trained to creatively develop 10 sentences based on the subject matter and theme, and then they have to upload the sentences to a predetermined learning blog. In addition, to develop the sentences, students are also given the task to assess (criticize) the sentences made by their classmates. Thus, this phase is also a phase of critical thinking training for the student.

In the phase of self-evaluation, students are trained to evaluate learning outcomes for themselves on each subject. They are also trained to find the problems faced in learning on each subject and what solutions they used to solve the problem. This phase is a phase of training honesty, critical thinking, and problem solving skills. In the evaluation phase, students are tested for mastery of theoretical concepts and the ability to write French. Finally, the closing phase is a phase to celebrate the learning and to explain the instruction about learning activities in the next meeting. Class celebrations can foster excitement and increase student motivation.

Third, the unity of the objectives, contents, and constructions system of Guided Autonomous Learning designs by integrating eight types of $21^{\text {st }}$ century skills is very effective in improving the quality of learning processes and outcomes. The unity of the objectives, contents, and constructions system of learning designs greatly facilitates students in carrying out learning activities both individually and in groups. When students open a learning blog writing French, they like using an electronic version of textbook and learn to use Guided Autonomous Learning model by integrating eight types of $21^{\text {st }}$ century skills. The using of Indonesian as instruction of textbook are also very helpful for student in learning autonomously. Thus, students do not rely much on lecturer explanations to understand the learning material. Learning in the classroom is not the activity of delivering material by lecturers but it is activity of deepening material between students and through lecturers explanations as additional explanations. This learning process is certainly very different from traditional learning classes where lecturers take a very dominant role.

In certain learning, lecturers usually develop learning plan based on the contents of textbooks that have been developed by the experts. Then, the lecturer chooses a model and learning media that have also been developed by the experts. In addition, many lecturers use evaluation instruments that have been developed by the experts. The strategies for developing a learning plan have strengths and weaknesses. The strength of the strategy is that teaching materials, learning model, learning media, and evaluation instruments used have met the validity elements at each of it. But The weaknesses of the strategy are that teaching materials, learning model, learning media, and evaluation instruments used do not necessarily have a unified objectives, contents, and constructions system so that it is not effectively used in learning. The Learning outcomes set in the syllabus will be difficult to be achieved if the learning designs used do not have the unity of objectives, contents, and constructions system.

In this research, the curriculum (syllabus) that integrates $21^{\text {st }}$ century skills has a wide range of learning outcomes, contents (materials), processes, and evaluations that require learning model, textbook, media, and special evaluation instruments that are in accordance with the characteristics of syllabus which has been developed. In this regard, the lecturers who use the syllabus that integrates 21 st century skills $21^{\text {st }}$ are advised to develop learning model, textbook, learning media, and evaluation instruments that are in accordance with the characteristics and learning outcomes of the courses. 


\section{Conclusion and Implication}

Based on the results of the study, the strategy to improve student's skills in witing French and 21st century skills for students through the use of Guided Autonomous Learning designs by integrating eight types of $21^{\text {st }}$ century skills is very effective to be used. In connection with the results, the curriculum based on the Indonesian National Qualification Framework should use the concept of integrated curriculum. Through this strategy, the number of the courses of expertise is not reduced and $21^{\text {st }}$ century skills can be trained to students continuously in each courses.

This study produced five learning designs, they are: (1) syllabus French writing courses by integrating eight types of $21^{\text {st }}$ century skills, (2) Guided Autonomous Learning model by integrating eight types of $21^{\text {st }}$ century skills, (3) textbook writing French by integrating eight types of $21^{\text {st }}$ century skills, (4) Guided Autonomous Learning media by integrating eight types of $21^{\text {st }}$ century skills, and (5) semester learning plan for courses of writing French by integrating eight types of $21^{\text {st }}$ century skills. The five learning designs have met the elements of validity, practicality, and effectiveness of learning designs. The average validity score of learning designs is 3.37 in the valid category. The average practicality score of learning designs is 3.56 with a very practical category. The score of learning designs effectiveness is 3.61 in the very effective category. The overall quality of learning design is in a very good category with an average score is 3.51 .

To develop a Guided Autonomous Learning designs by integrating eight types of $21^{\text {st }}$ century skills that are interconnected is needed a carefulness in determining which design must be developed first. Based on the results of this study, the sequence of developing learning designs begins with the development of syllabus, development of learning model, development of textbook, development of learning media, and development of semester learning plan.

Based on the results of the study found three things that influence the success of the study, they are: (1) the integration of $21^{\text {st }}$ century skills in the design of Guided Autonomous Learning design by integrating eight types of $21^{\text {st }}$ century skills is very effective used to improve learning outcomes in writing French and $21^{\text {st }}$ century skills for students, (2) external motivation has a very strong influence on the learning process and results, and (3) the unity of the objectives, contents and the constructs system of learning designs is very effective to improve the quality of the process and learning outcomes.

The implications of this study are (1) it's needed to develop the curriculum of Study Program that refers to the concept of integrated curriculum and (2) the Guided Autonomous Learning designs by integrating eight types of $21^{\text {st }}$ century skills should be developed in other subjects (courses).

\section{References}

Abidin, Yunus. (2015). Pembelajaran Multiliterasi. Bandung: PT Refika Aditama.

Arifin, Zainal. (2013). Konsep dan Model Pengembangan Kurikulum. Bandung: PT Remaja Rosdakarya.

Bradshaw, Zoe and Amanda Hazell, (2017) "Developing Problem-Solving Skills in Mathematics: A Lesson Study", International Journal of Lesson and Learning Studies, Vol. 6 Issue: 1, pp.32-44. 
English, F and Marr, T. (2015). Why do Linguistics ?: Reflective Linguistics and The Study of Language. London: Bloomsbury Academic.

Fenrich, Peter. (2005). Creating Instructional Multimedia Solutions: Practical Guidelines for the Real World. California: Informing Science Press.

Hanover Research. (2011). A Crosswalk of 21st Century Skills. Washington: Connecticut Ave.

Hidayat, Sholeh. (2013). Pengembangan Kurikulum Baru. Bandung: PT Adolescent Rosdakarya Offset.

Laxman, Kumar. (2013) "Infusing based learning skills in curriculum implementation", International Journal of Lesson and Learning Studies, Vol. 2 Issue: 1, pp.41-55.

Petra, Siti Fatimah, Jainatul Halida Jaidin, JSH Quintus Perera, Marcia Linn, (2016) "Supporting students to become autonomous learners: the role of web-based learning", The International Journal of Information and Learning Technology, Vol. 33 Issue: 4, pp.263-275.

Ranjan, Jayanthi. (2008) "Impact of information technology in academia", International Journal of Educational Management, Vol. 22 Issue: 5, pp. 422-455.

Staffan, Schedin, Osama A.B. Hassan, (2016) "Work integrated learning model in relation to CDIO standards", Journal of Applied Research in Higher Education, Vol. 8 Issue: 3, pp.278-286.

Strang, Kenneth David. (2015) "Effectiveness of instructor-led collaborative learning in the classroom", Journal of Applied Research in Higher Education, Vol. 7 Issue: 2, pp.134145.

Tong, Wanda \& Agnes Razniak, (2017) "Building professional capital within 21st century learning framework", Journal of Professional Capital and Community, Vol. 2 Issue: 1, pp.36-49.

Trianto. (2015). Model Pembelajaran Terintegrasi. Jakarta: PT Bumi Aksara.

Vishnu P. Murty, Kathryn C. Dickerson, (2016), Motivational Influences on Memory, In-ilKim, John Marshall Reeve, Mimi Bong (ed.) Recent Developments in Neuroscience Research on Human Motivation (Advances in Motivation and Achievement, Volume 19. Emerald Publishing Group Limited, pp.203 - 227.

Wang, L. (2014), "Curriculum and Curriculum Integration of Information Literacy in Higher Education", Developing People's Information Capabilities: Fostering Information Literacy in Educational, Workplace and Community Contexts (Library and Information Science, Vol. 8), Emerald Group Publishing Limited, pp. 31-49. https://doi.org/10.1108/S1876$\underline{0562(2013) 0000008007}$ 